\title{
I samtal för lärande och utveckling
}

Mona Fjellström*

Först och främst vill jag hälsa dig varmt välkommen till det första numret av Högre utbildning som publiceras via Cappelen Damm Förlag. Vi i redaktionen har haft ett intensivt år då vi i konstruktiva samtal med förlaget utformat och börjat använda den nya plattformen för tidskriften. Mycket fungerar som tidigare men en nyhet för dig som är läsare eller författare (eller både och) är att nya bidrag nu publiceras allt eftersom för att bilda ett nytt sammanhållet nummer när tillräckligt många bidrag antagits. En annan nyhet är att du också kan se nedladdningsstatistiken för dina publicerade bidrag.

Detta nummer innehåller frågeställningar, erfarenheter och resonemang som belyser den högre utbildningens utmaningar i flera av de nordiska länderna. Det skapar förutsättningar för gränsöverskridande samtal och lärdomar vi alla har glädje av. Det är vår förhoppning att du även fortsättningsvis ska finna tidskriftens artiklar intressanta och användbara i ditt arbete och i samtal med kollegor inom högre utbildning.

Att samtal med andra är en viktig förutsättning för lärande och utveckling belyses av flera bidrag i detta nummer av tidskriften. I artikeln Kamratrespons som formativ bedömning för lärande. En analys av kamratresponstexter på lärarutbildningen har Jennie Sivenbring studerat innehållet i den skrivna respons studenter tidigt i sin utbildning fått i uppgift att ge varandra. Studien visar att responsen formativt stöder lärandet för både den som ger och tar emot responsen men att det också är viktigt att studenterna får stöd och verktyg för hur de ska skriva sin respons. Kamratresponsen ger en grund för en förändrad pedagogisk praktik där studenterna också får möjlighet att utveckla sin kunskap om utvärdering och bedömning.

Studenters skrivande har varit ett intensivt diskussionsämne under en längre tid och en allt viktigare fråga är hur vi kan stötta studenternas förmåga att skriva. Minskande resurser för undervisning leder till att studenterna får ta ett större eget ansvar för sitt eget lärande samtidigt som undervisningen många gånger blir mer digital. Utmaningarna i denna utveckling belyses i två artiklar i detta nummer. I artikeln Stöttning av skrivande i ett digitalt diskussionsforum. Kan den digitala lärplattformens kursdesign utvecklas genrepedagogiskt? har Stina Hållsten studerat studenters skrivande på en distanskurs utifrån ett genrepedagogiskt perspektiv. Genrepedagogiken omfattar pedagogiska aktiviteter som stödjer tillägnandet av såväl ämnesinnehåll som ämnets språk. Aktiviteterna fokuserar på den muntliga dialogen kring text och innehåll. Vad innebär det när utbildningen är förlagd till lärplattformar? Kan den skriftliga, asynkrona diskussionen erbjuda det stöd som liknar det muntliga seminariesamtalet? Samtalet och återkopplingens betydelse för lärandet är också framträdande i Åsa Mickwitz artikel Mer handledning och feedback hade varit bra. När studenterna på en kurs i akademiskt skrivande tillfrågades om hur de uppfattade sin förmåga att självständigt sätta upp mål, utforma lärstrategier, finna tid och

\footnotetext{
* Författarkontakt: Mona Fjellström, Umeå universitet mona.fjellstrom@umu.se

(C)2017 Mona Fjellström. This is an Open Access article distributed under the terms of the Creative Commons Attribution-NonCommercial 4.0 International License (https://creativecommons.org/licenses/by-nc/4.0/), allowing third parties to share their work (copy, distribute, transmit) and to adapt it, under the condition that the authors are given credit, that the work is not used for commercial purposes, and that in the event of reuse or distribution, the terms of this license are made clear.

Citation: Mona Fjellström. (2017) "I samtal för lärande och utveckling», Högre utbildning 7(1), 98-99. http://dx.doi.org/10.23865/hu.v7.1075
} 
utvärdera sitt lärande i studier svarar studenterna att de själva klarar av att sätta upp mål och hantera tiden. Nästan hälften ansåg dock att de hade behövt respons på sina texter och handledning av en lärare under kursen för att kunna utveckla sitt skrivande. Hållstens och Mickwitz studier visar hur vi på flera sätt behöver utveckla pedagogiken och användningen av digitala verktyg för att bättre stötta studenternas skrivande.

Kan det också vara så att vi utformar undervisning som inte svarar mot eller utvecklar studenternas egna lärandestrategier? Som ställer för låga krav? Kim Herrman, Velda McCune och Anna Bager-Elsborg beskriver i artikeln Approaches to learning as predictors of academic achievement: Results from a large scale, multi-level analysis hur de i en enkätstudie med över 4000 studenter kommit fram till att det inte verkar finnas någon koppling mellan en djupinriktad lärstrategi och akademisk framgång. Att de och andra forskare kommit fram till denna slutsats reser frågor om både målsättningar och undervisningsstrategier i högre utbildning. Frågor till exempel om skillnader mellan olika utbildningsprogram och ämnen.

Utvecklingen av studenternas lärande under utbildningen beskrivs ofta i termer av progression och innebörden i det begreppet har Anna Ida Säfström tittat närmare på i artikeln Progression $i$ högre utbildning. Hennes dokumentanalys visar att progression används $\mathrm{i}$ allt högre utsträckning av både myndigheter och lärosäten, men ofta med oklar betydelse. Hennes analys visar att det har skett en förskjutning mot användning av ordet progression som kvalitet i meningen ökande, på varandra byggande, krav i utbildning. Hennes studie visar att vi behöver titta närmare på vad progression innebär i praktiken och det har Lars Larsson gjort i sin artikel Planering, progression, profession: hur studenter blir planerare där han undersökt hur progressionen för utbildningsmålen värderingsförmåga och förhållningssätt i samhällsplanerarprogrammet ser ut. De kunskaper som utvecklas med stöd i de nationella examensmålen för värderingsförmåga och förhållningssätt är de som ligger närmast den professionella identiteten. Kurser i kulturgeografi, som ingår i programmet, har analyserats utifrån förväntade studieresultat, läraktiviteter och examinationsformer i syfte att spåra den planerade progressionen. Analysen visar att progressionen är begränsad.

Ett gott exempel på hur man kan utforma utbildningsinslag för att belysa professionsnära utmaningar kan du läsa om i Lärdomar frän en simulering av humanitär förhandling av Lars Löfquist. Exemplet beskriver en simuleringsövning där studenter på masternivå får tillämpa teori och begrepp inom fredsbyggande och förhandlingsforskning i en konkret situation. Simuleringen som framförallt har ett processfokus gav möjligheter att också stödja affektivt lärande. Ta del av övningens planering, genomförande och utvärdering och gör ett eget försök.

Slutligen vill vi också slå ett slag för Tobias Hägerlands recension av Universitetskanslersämbetets vägledning Rättssäker examination som under 2017 utkommit i sin tredje upplaga. I recensionen uppmärksammas till exempel nya skrivningar om anonyma prov, examination med digitala hjälpmedel, examinationsspråk och anpassad examination. Dessutom lyfts ett antal punkter som skulle kunna tas upp i nästa utgåva av vägledningen. 